\title{
Assessment of Genetic Behavior of Some Selected Families from Local Okra Cultivar (Abelmoschus Esculentus L. Moench)
}

\author{
Essam M. A. Helmy and Entsar I. M. Ragheb
}

Vegetable Crops Department, Faculty of Agriculture, Alexandria University, Alexandria, Egypt. Received: 05 Oct. 2019 / Accepted 10 Dec. 2019 / Publication date: 30 Dec. 2019

\begin{abstract}
This study was planned to assess variability and heritability with genetic advance in okra, using 18 divers' families; which produced from three cycles of individual plant selection, Balady cultivar, during the three summer seasons of 2014, 2015 and 2016. The 18 selected families were grown in a randomized complete block design with three replications during summer 2017 at the Experimental Station Farm, Faculty of Agriculture, Alexandria University; at Abies, Alex, A.R.E. Observations that recorded on ten characters reflected considerable variability. The results indicated, also, that the all 18 selected families, that obtained after three cycles of individual plant selection; varied in their horticultural characteristics, and exhibited highly significant differences, with desirable effect, for all studied characters. Moreover, the mean performances showed uniform plants within each family; and a clear indication of agronomic superiority of some families over others, as well as, over the original population also was recorded. Mean values were used to determine characters' phenotypic and genotypic variances, phenotypic and genotypic coefficients of variation, broad sense heritability and genetic advance. Clear narrow range of different between PCV and GCV was observed for six characters from ten studied characters; plant height, internode length, branches number per plant, pod diameter, total pods number per plant and total pods weight per plant. High heritability along with high genetic advance as percent of the mean were obtained for total yield per plant, pods number per plant, branches number per plant, internode length and plant height revealing the importance of additive gene action in the inheritance of these characters and suggested reliable okra improvement through selection of these traits.
\end{abstract}

Keywords: Okra, Abelmoschus esculentus L. Moench, selection, PCV, PGV, heritability, genetic advance

\section{Introduction}

Okra (Abelmoschus esculentus L. Moench) is a member of the hibiscus family Malvaceae; which has captured a prominent position among the vegetables, as well as, is a popular vegetable in the world. Where, it is ancient and economically important vegetable crop cultivated throughout the world and is a native of Africa. Okra grown chiefly for its tender green pods for fresh consumption; but, sometimes in canned or dehydrated form. It is gaining importance with regard to its high nutritive and medicinal value.

Okra is polyploid in nature with $2 \mathrm{n}=8 \mathrm{x}=72$ to 144 chromosomes. There are 34 species in the world (Joshi and Hardas, 1956), out of them, Abelmoschus esculentus $(2 \mathrm{n}=130)$ is the only species identified to be cultivated widely. Although, okra is a self-pollinated crop; outcrossing to an extent of 20 per cent by insects with maximum of $42.2 \%$ (Mitidieri and Vencovsky, 1974). which cause a considerable amount of variability in size, pod shape, pigmentation, degree of branching, period of maturity, and plant height. In spite of okra crop importance, no major breakthrough has been made in this crop and the Egyptian farmers for generation are still growing their own local cultivars or open pollinated cultivars. It is therefore important that plant breeders developed their local cultivars of okra.

To turn okra into a perfect candidate for sustainable agriculture, the crop should be attractive to both producers and consumers in terms of yield and quality, respectively. Genetic improvement of okra or any crop mainly needs some knowledge about the nature and degree of variation existing in available breeding materials; to choose the suitable characters for effective selection of desirable

Corresponding Author: Entsar I. M. Ragheb, Vegetable Crops Department, Faculty of Agriculture, Alexandria University, Alexandria, Egypt.

E-mail: dr.entsar2110@gmail.com 
genotypes for making rapid improvement in yield and other desirable characters (Vavilov,1951); so, it is considered the first step in any crop improvement program (De Vicente et al., 2005).

The available literature reveals that before taking up any breeding program a thorough knowledge is required regarding the nature and magnitude of genetic variability, also, heritability and genetic advance. Heritability is the heritable portion of phenotypic variance; thus, estimates of heritability help plant breeder in selection of elite genotypes from varied genetic populations. Heritability indicates only the effectiveness with which selection of a genotype can be based on phenotypic performance; but it miss the mark to indicate the expected genetic improvement in one cycle of selection. Heritable variation can be effectively used with better degree of accuracy when heritability is studied in combined with genetic advance (Johanson et al., 1955). Genetic advance represents the improvement in the mean genotypic values of selected families over base population; therefore, helps the breeder to select the best progenies in the earlier generation. (Sravanthi, 2016). Thus, high variability and high heritability coupled with high genetic advance is a key to crop improvement.

Keeping these things in view, this study was planned to assess variability and heritability with genetic advance to select superior genotypes, for the further improvement in okra, Balady cultivar, using individual plant selection program.

\section{Materials and Methods}

The present trails were carried out at the Experimental Station Farm, Faculty of Agriculture, Alexandria University; at Abies, Alex, A.R.E., during four successive summer seasons of 2014, 215, 2016 and 2017.

\section{1- Plant material and selection procedure.}

The basic plant material, in this study, was Balady cultivar of okra; that its seeds were collected from different farmers in different governorate. Seeds of the original population of Balady cultivar were sown in a field experiment on March $15^{\text {th }}$ of 2014. All agricultural practices such as fertilization, irrigation and pest control were performed as usually recommended for commercial okra production, whenever they were thought necessary. The measurements of the different studied characters, on individual plant basis, were recorded through the practiced procedure of individual plant selection. Individual plant selection with selfing; to increase homozygousity in the next offspring, based on plant height, branching number per plant, internode length, yield and some pod characteristics was implemented. At the end of pods maturity stage, the seeds of the first selfed progenies, as well as, seeds of the original population were separately collected, extracted and stored to be used in the next cycle of individual plant selection. In the second and third seasons of 2015 and 2016, seeds of the selfed progenies of each selected plant were separately sown to initiate families; then, selection on the same forgoing basis, was also practiced within -and between- the selfed progenies of the individual selected plants to maintain the most promising plants of the third selfed progenies. The number of the finally selected progenies from the third selfed progenies of the selected plants came down to be 18 populations of Balady cultivar.

\section{2- Horticultural evaluation trail.}

In the fourth summer season of 2017, a field experiment was carried out in order to evaluate the efficiency of three cycles of individual plant selection for three generations of selfing with selection on the variability and general performances of the studied characters. In this experiment, seeds of the Balady cultivar as the original population $\left(\mathrm{C}_{0}\right)$ and those of the 18 third selfed progenies of the individual plant selection $\left(S_{3}-1\right.$ to $\left.S_{3}-18\right)$ as were separately sown in a randomized complete block design with three replicates. Each plot was represented by three rows $4 \mathrm{~m}$. long and $0.70 \mathrm{~m}$. wide, and $0.30 \mathrm{~m}$. between plants. All cultural practices such as fertilization, irrigation and plant protection against weeds, diseases and insects; were performed whenever they were necessary, as recommended for okra production in Egypt. The data were recorded and measured for all studied characters, as previously mentioned, to be used in the estimation of the different statistical and genetic parameters. 


\section{3- Data collected.}

Data on ten traits were recorded from 10 randomly selected plants from each plot, which includes: plant height $(\mathrm{cm})$, internode length $(\mathrm{cm})$, branches number per plant, pod length $(\mathrm{cm})$, pod diameter $(\mathrm{cm})$, pod weight $(\mathrm{g})$, pods number per main stem, pods number per branches, total pods number per plant and pod yield per plant $(\mathrm{g})$.

\section{4- Statistical analysis and estimation of genetic parameters.}

The mean values of each character under the study were computed and subjected to analysis of variance, following the procedures described by Al-Rawi and Khalf-Allah (1980), using Co-Stat computer software program (2004).

The components of variance were estimated using the observed mean square values as outlined by Johanson et al., 1955; using the following formulae:

$$
\sigma_{\mathrm{g}}^{2}=\left(\mathrm{MS}_{\mathrm{g}}-\mathrm{MS}_{\mathrm{e}}\right) / \mathrm{r}, \quad \sigma_{\mathrm{e}}^{2}=\mathrm{MS}_{\mathrm{e}} \quad \text { and } \quad \sigma_{\mathrm{p}}^{2}=\sigma_{\mathrm{g}}^{2}+\sigma_{\mathrm{e}}^{2}
$$

where $\sigma_{\mathrm{g}}^{2}, \sigma_{\mathrm{e}}^{2}$ and $\sigma_{\mathrm{p}}^{2}$ are the variances due to genotypes, experimental error and phenotypes, respectively. $\mathrm{MS}_{\mathrm{g}}, \mathrm{MS}_{\mathrm{e}}$ and $\mathrm{r}$ are the mean squares of genotypes, mean squares of error and number of replicates, respectively.

Phenotypic (PCV) and genotypic (GCV) coefficient of variation were evaluated according to the methods of Johnson et al., 1955 and Hanson et al., 1956 as follows:

$\mathrm{PCV}=\left[\sqrt{ } \sigma_{\mathrm{p}}^{2} / \mathrm{X}\right] \overline{\mathrm{x} 100}$

$\mathrm{GCV}==\left[\sqrt{ } \sigma_{\mathrm{g}}^{2} / \mathrm{X}\right] \times 100$

Where $\sigma_{p}^{2}, \sigma_{g}^{2}$ and $X$ are the phenotypic variances, genotypic variances and grand mean for each trait, respectively.

Broad sense heritability $\left(\mathrm{H}^{2}\right.$ bs $\left.\%\right)$ was calculated according to Allard, 1999 as the ratio of the genotypic variance $\left(\sigma_{\mathrm{g}}^{2}\right)$ to the phenotypic variance $\left(\sigma_{\mathrm{p}}^{2}\right)$.

$\mathrm{H}^{2}{ }_{\mathrm{bs}} \%=\sigma_{\mathrm{g}}^{2} / \sigma_{\mathrm{p}}^{2} \mathrm{X} 100$

Expected genetic advance (GA) after three generations of selection and GAM as percentage of the mean assuming selection of the superior $5 \%$ of the genotypes were estimated according to the formula given by Johnson et al., 1955 as follows:

$\mathrm{GA}=\mathrm{kh}^{2}{ }_{\mathrm{bs}} \sqrt{ } \sigma_{\mathrm{ph}}^{2}$

$\mathrm{GAM}($ as $\%$ of the mean $)=(\mathrm{GA} / \mathrm{X}) \times 100$

Where $\mathrm{k}$ is the selection differential (2.06 for selecting $5 \%$ of the genotypes).

\section{Results and Discussion}

\section{1- Evaluation behavior of the selected families after three cycles of individual plant selection.}

Data in Table 1 reflected wide variation among the evaluated families for plant height character with significant differences between all selected families and their original population. Among the selected families; significantly the tallest plant $\left(172.13 \mathrm{~cm}\right.$ ) belongs to family $\mathrm{S}_{3}-18$; whereas, family $\mathrm{S}_{3}-6$ exhibited the shortest plant height $(96.13 \mathrm{~cm})$. The tallest internode length was recorded by the four families $S_{3}-3, S_{3}-8, S_{3}-9$ and $S_{3}-17$ with mean values $6.81,6.98,6.99$ and $7.00 \mathrm{~cm}$, respectively; whereas, $\mathrm{S}_{3}-11$ recorded the shortest internode length $(4.27 \mathrm{~cm})$. For branches number per plant, family $\mathrm{S}_{3}-18$ showed the abundant plants (5.00) among the all-selected families; which did not differ significantly from the original population; whereas, the lowest branches number per plant (1.01) was given by the two families $S_{3}-2$ and $S_{3}-10$; which did not differ significantly from the three selected families $S_{3}-1, S_{3}-7$ and $S_{3}-11$. 
Concerning fruit characteristics, data in Table 1 revealed that the two families $\mathrm{S}_{3}-6$ and $\mathrm{S}_{3}-14$ possessed the tallest pod length $(5.21$ and $5.20 \mathrm{~cm}$, respectively), whereas, the shortest pod length were recorded by the family $\mathrm{S}_{3}-17(3.01 \mathrm{~cm})$. With respect to pod diameter, the two families $\mathrm{S}_{3}-17$ and $\mathrm{S}_{3}-10$ exhibited the lowest mean values (1.01 and $1.05 \mathrm{~cm}$, respectively). Moreover, data in Table 2 reported that; among all families and original population; significantly the largest pod weight was obtained by $\mathrm{S}_{3}-6$ and $\mathrm{S}_{3}-7$ with the same mean value $(4.91 \mathrm{~g})$. Regarding yield characteristics, Table 2 , it is notable that all of the selected families exceeded the original population, Balady cultivar. The largest pods number per main stem was recorded by $S_{3}-11$ with mean value 28.05 , followed by $S_{3}-15$, $\mathrm{S}_{3}-7$ and $\mathrm{S}_{3}-18$ with mean values as $25.69,25.02$ and 25.01 ; which did not reflect any significant differences between one another. While, significantly the largest pods number per branches was given by the family $\mathrm{S}_{3}-13$ (50.01); which differed significantly from all selected families, as well as, the original population. Similarly, the family $\mathrm{S}_{3}-13$ significantly produced the largest total pods number per plant and total yield per plant (70.00 and $280.08 \mathrm{~g}$, respectively); while, the original population showed significantly the lowest yield per plant (105.31 g).

Table 1: Mean performances of the 18 selected okra families and their original population, Balady cultivar, for the various studied characters.

\begin{tabular}{|c|c|c|c|c|c|}
\hline $\begin{array}{l}\text { Characters } \\
\text { Genotypes }\end{array}$ & $\begin{array}{c}\text { Plant } \\
\text { Height } \\
\text { (cm) }\end{array}$ & $\begin{array}{l}\text { Internode } \\
\text { length } \\
\text { (cm) }\end{array}$ & $\begin{array}{c}\text { Branches No. } \\
\text { per plant }\end{array}$ & $\begin{array}{c}\text { Pod } \\
\text { Length } \\
\text { (cm) }\end{array}$ & $\begin{array}{c}\text { Pod } \\
\text { diameter } \\
(\mathrm{cm})\end{array}$ \\
\hline$S_{3}-1$ & $125.61 \mathrm{f}-\mathrm{h}$ & $4.69 \mathrm{fg}$ & $1.10 \mathrm{e}$ & $3.78 \mathrm{c}-\mathrm{f}$ & $1.47 \mathrm{~b}$ \\
\hline$S_{3}-2$ & $105.68 \mathrm{j}-1$ & $5.55 \mathrm{de}$ & $1.01 \mathrm{e}$ & $4.54 \mathrm{a}-\mathrm{d}$ & $1.33 \mathrm{bc}$ \\
\hline $\mathbf{S}_{3}-\mathbf{3}$ & $150.32 \mathrm{c}$ & $6.81 \mathrm{ab}$ & $2.01 \mathrm{~d}$ & $3.51 \mathrm{ef}$ & $1.22 \mathrm{~cd}$ \\
\hline$S_{3}-4$ & $102.68 \mathrm{kl}$ & $5.34 \mathrm{ef}$ & $2.81 \mathrm{c}$ & $3.70 \mathrm{~d}-\mathrm{f}$ & $1.22 \mathrm{~cd}$ \\
\hline$S_{3}-5$ & $120.13 \mathrm{~g}-\mathrm{i}$ & $6.00 \mathrm{~cd}$ & $4.01 \mathrm{~b}$ & $4.00 \mathrm{c}-\mathrm{e}$ & $1.11 \mathrm{de}$ \\
\hline$S_{3}-6$ & 96.131 & $6.40 \mathrm{bc}$ & $3.03 \mathrm{c}$ & $5.21 \mathrm{a}$ & $1.33 \mathrm{bc}$ \\
\hline$S_{3-7}$ & $116.89 \mathrm{~h}-\mathrm{j}$ & $4.60 \mathrm{~g}$ & $1.03 \mathrm{e}$ & $5.00 \mathrm{ab}$ & $1.30 \mathrm{c}$ \\
\hline$S_{3}-8$ & $142.86 \mathrm{~cd}$ & $6.98 \mathrm{ab}$ & $2.02 \mathrm{~d}$ & $4.18 \mathrm{~b}-\mathrm{e}$ & $1.22 \mathrm{~cd}$ \\
\hline$S_{3}-9$ & $134.86 \mathrm{~d}-\mathrm{f}$ & $6.99 \mathrm{ab}$ & $2.01 \mathrm{~d}$ & $4.20 \mathrm{~b}-\mathrm{e}$ & $1.20 \mathrm{~cd}$ \\
\hline$S_{3}-10$ & $125.14 \mathrm{f}-\mathrm{h}$ & $4.50 \mathrm{~g}$ & $1.01 \mathrm{e}$ & $4.21 \mathrm{~b}-\mathrm{e}$ & $1.05 \mathrm{e}$ \\
\hline$S_{3}-11$ & $120.00 \mathrm{~g}-\mathrm{i}$ & $4.27 \mathrm{~g}$ & $1.03 \mathrm{e}$ & $5.01 \mathrm{ab}$ & $1.22 \mathrm{~cd}$ \\
\hline$S_{3}-12$ & $110.14 \mathrm{i}-\mathrm{k}$ & $5.50 \mathrm{de}$ & $3.02 \mathrm{c}$ & $4.54 \mathrm{a}-\mathrm{d}$ & $1.20 \mathrm{~cd}$ \\
\hline$S_{3}-13$ & $110.08 \mathrm{i}-\mathrm{k}$ & $5.50 \mathrm{de}$ & $4.01 \mathrm{~b}$ & $4.61 \mathrm{a}-\mathrm{c}$ & $1.33 \mathrm{bc}$ \\
\hline$S_{3}-14$ & $110.08 \mathrm{i}-\mathrm{k}$ & $5.51 \mathrm{de}$ & $3.01 \mathrm{c}$ & $5.20 \mathrm{a}$ & $1.24 \mathrm{~cd}$ \\
\hline$S_{3}-15$ & $130.31 \mathrm{c}-\mathrm{e}$ & $5.59 \mathrm{de}$ & $2.00 \mathrm{~d}$ & $4.54 \mathrm{a}-\mathrm{d}$ & $1.11 \mathrm{de}$ \\
\hline$S_{3}-16$ & $130.18 \mathrm{e}-\mathrm{g}$ & $6.52 \mathrm{bc}$ & $1.99 \mathrm{~d}$ & $5.01 \mathrm{ab}$ & $1.21 \mathrm{~cd}$ \\
\hline$S_{3}-17$ & $98.85 \mathrm{kl}$ & $7.00 \mathrm{ab}$ & $4.00 \mathrm{~b}$ & $3.01 \mathrm{f}$ & $1.01 \mathrm{e}$ \\
\hline$S_{3}-18$ & $172.13 \mathrm{~b}$ & $6.46 \mathrm{bc}$ & $5.00 \mathrm{a}$ & $4.21 \mathrm{~b}-\mathrm{e}$ & $1.28 \mathrm{c}$ \\
\hline Original pop. & $195.15 \mathrm{a}$ & $7.31 \mathrm{a}$ & $5.12 \mathrm{a}$ & $4.16 \mathrm{~b}-\mathrm{e}$ & $2.19 \mathrm{a}$ \\
\hline
\end{tabular}

Values having the same alphabetical letter (s) within each column, don't significantly differ from one another, using Duncan's multiple range test at 0.05 level of probability.

\section{2- Response to selection program}

According to comparing means of different selected families, as well as, their original population; the obtained results, generally, indicated, clearly, that the all 18 selected families varied in their horticultural characteristics after three cycles of individual plant selection, and exhibited highly significant differences, with desirable effect, for all studied characters. Comparing their mean performances showed, also, a clear indication of agronomic superiority of some families over others, as well as, over the original population. Moreover, the obtained results indicate that using three cycles of individual plant selection was found to be highly efficient in increasing the means of the yield characters; pods number per main stem, pods number per branches, total pods number per plant and total yield per plant relative to that of the original population. Meanwhile, such selection method was 
able to reduce the mean values, with desirable effect, of plant height, internode length, main branches number and pod diameter relative to the original population. On the contrary, the other two characters; pod length and pod weight reflected slight differences between one another and with the original population. From the previously mention results could be evident that most of the selected families surpassed the local cultivar. These results proved the efficiency of selection breeding for developing superior populations of okra after three cycles of individual plant selection. Similar results were obtained by Masoud et al., (2007); Reddy et al., (2012); Ibrahim et al., (2013) and Ibrahim et al., (2018).

Table 2: Mean performances of the 18 selected okra families and their original population, Balady cultivar, for the various studied characters.

\begin{tabular}{|c|c|c|c|c|c|}
\hline $\begin{array}{l}\text { Characters } \\
\text { Genotypes }\end{array}$ & $\begin{array}{c}\text { Pod } \\
\text { weight (g) }\end{array}$ & $\begin{array}{c}\text { Pods No. } \\
\text { per main stem }\end{array}$ & $\begin{array}{c}\text { Pods No. } \\
\text { per branches }\end{array}$ & $\begin{array}{l}\text { Total pods No. } \\
\text { per plant }\end{array}$ & $\begin{array}{l}\text { Total yield per } \\
\text { plant (g) }\end{array}$ \\
\hline$S_{3}-1$ & $3.69 \mathrm{~g}$ & $24.63 \mathrm{a}-\mathrm{c}$ & 20.95 ef & $43.64 \mathrm{f}-\mathrm{h}$ & $170.99 \mathrm{~g}$ \\
\hline$S_{3}-2$ & $4.54 \mathrm{bd}$ & $19.08 \mathrm{~d}-\mathrm{f}$ & $10.11 \mathrm{~g}$ & $29.08 \mathrm{i}$ & $130.64 \mathrm{i}$ \\
\hline$S_{3}-3$ & $3.53 \mathrm{gh}$ & $22.04 \mathrm{~b}-\mathrm{d}$ & 20.04 ef & $42.09 \mathrm{gh}$ & $148.74 \mathrm{~h}$ \\
\hline$S_{3}-4$ & $3.63 \mathrm{gh}$ & $19.00 \mathrm{~d}-\mathrm{f}$ & $28.16 \mathrm{~cd}$ & 46.94 ef & $171.36 \mathrm{~g}$ \\
\hline$S_{3}-5$ & $3.63 \mathrm{gh}$ & $20.05 \mathrm{c}-\mathrm{e}$ & $38.16 \mathrm{~cd}$ & $59.06 \mathrm{~b}$ & $215.23 \mathrm{de}$ \\
\hline$S_{3}-6$ & $4.91 \mathrm{a}$ & $15.09 \mathrm{fg}$ & $24.99 \mathrm{de}$ & $30.04 \mathrm{i}$ & $148.06 \mathrm{~h}$ \\
\hline$S_{3}-7$ & $4.91 \mathrm{a}$ & $25.02 \mathrm{ab}$ & $15.12 \mathrm{fg}$ & $30.08 \mathrm{i}$ & $149.01 \mathrm{~h}$ \\
\hline$S_{3}-8$ & $4.74 \mathrm{ab}$ & $20.03 \mathrm{c}-\mathrm{e}$ & $20.02 \mathrm{ef}$ & $40.05 \mathrm{~h}$ & $191.18 \mathrm{f}$ \\
\hline$S_{3}-9$ & $4.31 \mathrm{de}$ & $19.01 \mathrm{~d}-\mathrm{f}$ & $22.11 \mathrm{e}$ & $41.07 \mathrm{~h}$ & $177.09 \mathrm{~g}$ \\
\hline$S_{3}-10$ & $3.53 \mathrm{~h}$ & $20.08 \mathrm{c}-\mathrm{e}$ & $20.04 \mathrm{ef}$ & $40.21 \mathrm{~h}$ & $141.33 \mathrm{hi}$ \\
\hline$S_{3}-11$ & $4.58 \mathrm{bc}$ & $28.05 \mathrm{a}$ & $15.08 \mathrm{fg}$ & $43.09 \mathrm{gh}$ & $211.533 \mathrm{e}$ \\
\hline$S_{3}-12$ & $4.72 \mathrm{ab}$ & $20.04 \mathrm{c}-\mathrm{e}$ & $30.00 \mathrm{~cd}$ & $50.04 \mathrm{de}$ & $235.00 \mathrm{bc}$ \\
\hline$S_{3}-13$ & $4.00 \mathrm{f}$ & $20.01 \mathrm{c}-\mathrm{e}$ & $50.01 \mathrm{a}$ & $70.00 \mathrm{a}$ & $280.08 \mathrm{a}$ \\
\hline$S_{3}-14$ & $4.41 \mathrm{c}-\mathrm{e}$ & $20.02 \mathrm{c}-\mathrm{e}$ & $29.01 \mathrm{~cd}$ & $49.38 \mathrm{de}$ & $215.40 \mathrm{de}$ \\
\hline$S_{3}-15$ & $3.43 \mathrm{~h}$ & $25.69 \mathrm{ab}$ & $15.14 \mathrm{fg}$ & $40.72 \mathrm{~h}$ & $136.27 \mathrm{i}$ \\
\hline$S_{3}-16$ & $4.63 \mathrm{bc}$ & $20.00 \mathrm{c}-\mathrm{e}$ & $32.05 \mathrm{c}$ & $5203 \mathrm{~cd}$ & $242.21 \mathrm{~b}$ \\
\hline$S_{3}-17$ & $2.52 \mathrm{j}$ & $14.19 \mathrm{~g}$ & $40.01 \mathrm{~b}$ & $54.05 \mathrm{c}$ & $135.17 \mathrm{~cd}$ \\
\hline$S_{3}-18$ & $2.92 \mathrm{i}$ & $25.01 \mathrm{ab}$ & $42.08 \mathrm{~b}$ & $67.03 \mathrm{a}$ & $224.16 \mathrm{~cd}$ \\
\hline Original pop. & $4.30 \mathrm{e}$ & $17.18 \mathrm{e}-\mathrm{g}$ & $28.01 \mathrm{~cd}$ & $45.06 \mathrm{fg}$ & $105.31 \mathrm{j}$ \\
\hline
\end{tabular}

Values having the same alphabetical letter (s) within each column, don't significantly differ from one another, using Duncan's multiple range test at 0.05 level of probability.

\section{3- Phenotypic and genotypic coefficient of variation}

Data in Table 3 revealed that the magnitude both of phenotypic and genotypic coefficients of variation varied from one trait to another. Generally, the phenotypic coefficient of variation (PCV) was higher than genotypic coefficient of variation (GCV) for all studied traits. In particular, higher PCV and GCV estimates were recorded in the four characters; branches number per plant, pods number per branches, total yield per plant and plant height. While, the other six characters reflected moderate PCV and GCV values that ranged from 11.49-16.44 for GCV and 16.54-19.64 for PCV. The results illustrated, also, that clear narrow range of different between PCV and GCV was observed for the six characters from ten studied characters; plant height, internode length, branches number per plant, pod diameter, total pods number per plant and total pods weight per plant. The narrow range between PCV and GCV indicating less environmental influence on the phenotypic expression of these traits and they are mostly governed by genetic factors. Hence, selection of desired character simply on the phenotypic value may be effective. Moreover; high magnitude of PCV and GCV for above characters suggested greater phenotypic and genotypic variability among the different genotypes and indicated that these characters can be improved through phenotypic selection. These results confirm the earlier findings of (Kandasamy, 2015; Jadhav et al., 2016 and Shivaramegowda et al., 2016) for plant height; (Kumar and Kumar, 2014; Patel et al., 2014; Saryam et al., 2015; Jadhave et al., 2016) 
for number of branches ; ( Vani et al., 2012 and Sundaram and Rajkumar, 2015) for internode length; (Khajuria et al., 2015; Sundaram, and Rajkumar, 2015 and Kerure et al., 2017) for pods number per plant and (Kandasamy, 2015; Jadhav et al., 2016 and Kerure et al., 2017) for fruit yield per plant. These finding indicated greater to moderate genetic variability among the genotypes for these attributes; which offer considerable scope for improvement by selection program. Where, estimating variability in a population is an effective tool for breeder to design the selection procedures more accurately for identifying superior genotypes. Although the genotypic coefficient of variation revealed the extent of genotypic variability present in the genotypes for various traits, it does not provide full scope to assess the variation that is heritable. As stated by Burton (1953), the genotypic coefficient of variations along with heritability estimates provide reliable estimate of the amount of genotypic advance to be expected through phenotypic selection.

Table 3: Genetic estimate of ten studied characters in 18 selected families of okra after three cycles of individual plant selection

\begin{tabular}{lccccccc}
\hline \multicolumn{1}{c}{ Parameters } & $\boldsymbol{\sigma}_{\mathbf{g}}^{\mathbf{g}}$ & $\boldsymbol{\sigma}_{\mathbf{p}}^{\mathbf{2}}$ & $\mathbf{G C V}$ & $\mathbf{P C V}$ & $\mathbf{H}^{\mathbf{2}} \mathbf{\text { b.s.}} \boldsymbol{\%}$ & $\mathbf{G A}$ & $\mathbf{G A} \mathbf{M}$ \\
\hline Plant height (cm) & 625.85 & 676.15 & 19.83 & 20.61 & 92.56 & 49.54 & 39.27 \\
Internode length (cm) & 0.788 & 0.943 & 15.12 & 16.54 & 83.56 & 2.54 & 98.07 \\
Branches number per plant & 1.688 & 1.871 & 50.16 & 52.81 & 90.22 & 1.67 & 28.42 \\
Pod length (cm) & 0.25 & 0.545 & 11.49 & 16.97 & 45.87 & 0.47 & 10.86 \\
Pod diameter (cm) & 0.047 & 0.053 & 16.93 & 17.99 & 88.68 & 0.42 & 0.33 \\
Pod weight (g) & 0.403 & 0.602 & 16.44 & 20.1 & 66.94 & 1.07 & 27.67 \\
Pods No. per stem & 10.18 & 16.61 & 15.38 & 19.64 & 61.29 & 5.14 & 24.75 \\
Pods No. per branches & 7.612 & 18.28 & 20.45 & 26.39 & 41.73 & 3.67 & 13.99 \\
Total pods number per plant & 124.23 & 129.58 & 16.58 & 16.93 & 95.87 & 22.47 & 33.44 \\
Total yield per plant (g) & 2156.55 & 2201.03 & 25.73 & 25.99 & 97.98 & 94.62 & 52.43 \\
\hline
\end{tabular}

\section{Heritability and genetic advance}

High broad sense heritability values, in Table 3, were recorded for all studied characters, which were found to be in the range of $83.56 \%$ for internode length character up to $97.98 \%$ for total yield per plant, with four exceptions. These exceptions were noticed in the estimated values of broad sense heritability for the characters pod weight, pods number per stem, pod length and pods number per branches; which were recorded moderate values that estimated by $66.94 \%, 61.29 \%, 45.87 \%$ and $41.73 \%$, respectively. The heritability estimate provides the information on the magnitude of inheritance of quantitative characters but does not indicate the magnitude of genetic gain obtained by selection of best individual from the best population. So, heritability along with genetic advance is more useful than the heritability alone. In the present study, the estimates of genetic advance were found to be in the range from 0.42 for pod diameter to 94.62 for total yield per plant. Generally, the results showed that the genetic advance values were considered high to moderate for the all studied characters, with the exception of the two characters pod diameter and pod length. Comparatively, high values of genetic advance as percent of the mean were recorded for internode length, followed by total yield per plant, plant height, pods number per plant, branches number per plant, pod weight and pods number per stem. This indicates that selecting the top $5 \%$ of the genotypes could make an advance of internode length in $98.07 \%$, total yield per plant in $54.43 \%$, plant height in $39.27 \%$, pods number per plant $33.44 \%$, branches number per plant in $28.42 \%$, pod weight in $27.67 \%$ and pods number per stem in $24.75 \%$. High heritability along with high genetic advance is an important factor for expecting the resultant effect for selecting the top individuals. In the present investigation, high heritability along with high genetic advance as percent of the mean were obtained for total yield per plant, pods number per plant, branches number per plant, internode length and plant height. Similar observation was recorded in okra by Singh et al., (2006); Manivannan et al., (2007); Akother et al., (2010); Adiger et al., (2011); Oluwa and Kehinde, (2011); Patel et al., (2014) and Yonus et al., (2014). High heritability coupled with high genetic advance reflected the involvement of additive gene action; therefore, improvement in these traits would be more effectively be done through selection in the present 
material. On the other hand, the character pod diameter exhibited relatively moderate genetic advance; however, their heritability estimates were high; that reflected implied equal importance of additive and non-additive gene action. The high heritability might be due to unfavorable influence of environment rather than genetic constitution and offers a little scope for selection.

\section{Conclusion}

Based upon the present investigation, it is suggested that the genetic variability reported for different characters in relation to pod yield will be worthwhile. For future genetic improvement of okra and the characters showing high heritability with high genetic advance viz., total yield per plant, pods number per plant, branches number per plant, internode length and plant height; that should be utilized in direct selection; further, could be stated that with selection improvement program continuing, a better outcome can be achieved after a number of selection generations. Also, the selected families; $S_{3}-13, S_{3}-16$ and $S_{3}-18$, that performed best in this study can be further for selection breeding program.

\section{References}

Adiger, S.G., P.I. Shanthkumar; and P.M. Salimath, 2011. Association studies in okra (Abelmoschus esculentus L. Moench). Electron. J. Pl. Breed., 2(4): 568 - 573.

Akother, P.K., D.K. De and A.K. Pal. 2010. Genetic variability and diversity in okra (Abelmoschus esculentus L. Moench). Electron. J. P1. Breed, 1(4): 393 - 398.

Allard, R.W. 1999. Principles of Plant Breeding, 2nd Edt., John Wiley and Sons, New York. pp. 254.

Al-Rawi, K.M., and A.M. Khalf-Allah, 1980. Design and analysis of agriculture experiments. Text book. El Mousil Univ. Press. Ninawa, Iraq, 487.

Burton, G.W., and E.H. Devane, 1953. Estimating heritability in tall Fescue (Festuce arundinacea) from replicated clonal material. Agro. J., 45:478 - 481.

Co-State Software. 2004. User's manual version. Cohort Tusson, Arizona, USA.

De Vicente, M.C., F.A. Guzman, J. Engels and V.R. Rao, 2005. Genetic characterization and its use in decision making for the conservation of crop Germplasm. The Role of Biotechnology, March 5-7, 2005, Villa Gualino, Turin, Italy.

Hanson, C.H., H.F. Robinson, and R.E. Comstock, 1956. Biometrical studies of yield in segregating populations of Korean Lespedeza. Agron. J., 48: 268-272.

Ibrahim E.A., M.Y. Abed and A.M. Moghazy. 2013. Genetic behavior of families selected from some local okra (Abelmoschus esculentus L. Moench) population in Egypt. Plant Breed. Biotech. 1(4): $396-405$.

Ibrahim, E.A., M.Y. Abed and A.M. Moghazy, 2018. Improving some economical traits of local okra (Abelmoschus esculentus L. Moench) through selection and inbreeding.

Jadhave, R.A., S.B. Bagwale, L.N. Jawale and D.B. Deosarkar, 2016. Genetic variability studies for yield, yield contributing and quality traits in okra (Abelmoschus esculentus L. Moench). Indian J. Agric. Res., 50(6): $614-618$.

Johnson, H.W., H.F. Rabinson and R.E. Comstock, 1955. Estimate of genetic and environmental variability in soybean. Agron. J., 47: 314-318.

Joshi, A.B. and M.W. Hardas, 1956. Alloploid nature of okra (Abelmoschus esculentus L. Moench). Nature, 178: 1190 - 1191.

Kandasamy, R., 2015. Variability studies in okra (Abelmoschus esculentus L. Moench). The Asian J. Hort., 10(1): $60-63$.

Kerure, P., M. Pitchaimuthu and A. Hosamani, 2017. Studies on variability, correlation and path analysis of traits contributing to fruit yield and its components in okra (Abelmoschus esculentus L. Moench). Elec. J. Pl. Bree., 8(1): $134-141$.

Khaiuria, R.K., J.P. Sharma, R.K. Samnotra, S. Kumar and K. Ranjit. 2015. Variability studies in okra (Abelmoschus esculentus L. Moench). Elec. J. Pl. Bree., 226 - 234.

Kumar, P. and R. Kumar, 2014. Variability, heritability and character association in okra (Abelmoschus esculentus L. Moench). Asian J. Bio Sci., 9(1): 9 - 13.

Manivannan, M.I., J. Rajangam and P. Geetharani, 2007. Variation studies in okra. Asian J. Hort. 2(2): $188-191$. 
Masoud, A.M., Y.B. El-Waraky, T.A. Shalaby and M.H. Kasem, 2007. Developing new strains of okra. J. Agric. Sci. Mansoura Univ., 32: 583 - 590.

Mitidieri, J. and R. Vencovsky, 1974. Rivista de Agriculture. Brazil, 49:3-6.

Oluwa, O.O. and O.B. Kehinde. 2011. Genetic variability studies in West Africa okra (Abelmoschus caillei). Agric. Biol. J. N. Am., 2(10): 1326 - 1335.

Patel, R., S.K. Sengupta and A.K. Verma, 2014. Studies on genetic parameters in okra (Abelmoschus esculentus L. Moench). Trends in Biosciences, 7(14): 1808 - 1811.

Reddy, M.; K. Hari Babu; M. Ganesh; K. Reddy; H. Begum; B. Reddy and G. Narshimulu, 2012. Genetic variability analysis for the selection of elite genotypes based on pod yield and quality from the germplasm of okra (Abelmoschus esculentus L. Moench). J. Agric. Technology. 8(2): $639-655$.

Saryam, D.K., S.K. Mittra, S. Prajapati, O.P. Singh and A.K. Mehta, 2015. Assessment of genetic variability for various yield and yield attributing trait in okra (Abelmoschus esculentus L. Moench) under kymore plateau \& satpura hills agro-climatic regions of Madhya Pradesh. Current Advances in Agric. Sci., 7(2): 177 - 179.

Shivaramegowda, K.D., A. Krishnan, Y.K. Jayaramu, V. Kumar, Yashoda and K. Hee-Jong, 2016. Genotypic variation among okra (Abelmoschus esculentus L. Moench) germplasms in south India. Plant Breed. Biotech, 4(2): $234-241$.

Singh, B., A.K. Pal and S. Singh, 2006. Genetic variability, correlation and path analysis in okra (Abelmoschus esculentus L. Moench). Indian J. Hort., 63(3): 281 - 285.

Sravanthi, U., 2016. Studies on variability, heritability and genetic advance in okra (Abelmoschus esculentus L. Moench). Journal of Agricultural Engineering and Food Technology.

Sundaram, V. and P. Rajkumar, 2015. Genetic analysis in okra (Abelmoschus esculentus L. Moench). The Asian J. Horticulture, 10(1): $173-176$.

Vani, V.M., A.K. Singh, S.V. Raju, B.K. Singh and S.P. Singh. 2012. Variability studies in okra (Abelmoschus esculentus L. Moench). Environment \& Ecology, 30(3C): 1203 - 1206.

Vavilov, N.I., 1951. The origin, variation, immunity and breeding of cultivated plants. Chron. Bot., 13: 1949-1950.

Yonus, M., W. Garedew and A. Debela, 2014. Variability and association of quantitative characters among okra (Abelmoschus esculentus L. Moench) collection in south western Ethiopia. J. Biol. Sci., 14(5): $336-342$. 